\title{
Effect of biochar composite and organic sources on soil properties and yield of bhendi (Abelmoschus esculentus L.)
}

\section{B. Karthikeyan*}

Department of Soils and Environment, Agricultural College and Research Institute, Madurai - 625104 (Tamil Nadu), India

\section{B. Bhakiyathu Saliha}

Department of Soil Science and Agricultural Chemistry, Agricultural College and Research Institute, Killikulam, Thoothukudi district - 628252 (Tamil Nadu), India

\section{P. Kannan}

Department of Soils and Environment, Agricultural College and Research Institute, Madurai - 625104 (Tamil Nadu), India

\section{S. Vellaikumar}

Department of Biotechnology, Agricultural College and Research Institute, Madurai - 625104 (Tamil Nadu), India

*Corresponding author. E mail: karthikeyankarthi09011998@gmail.com

\section{How to Cite}

Karthikeyan, B. et al. (2021). Effect of biochar composite and organic sources on soil properties and yield of bhendi (Abelmoschus esculentus L.). Journal of Applied and Natural Science, 13(4), 1198 - 1205. https://doi.org/10.31018/jans.v13i4.2972

\begin{abstract}
Biochar is considered as a possible and potential tool for soil fertility improvement, climate change mitigation and long tem sink for atmospheric carbon dioxide. Soil application of biochar enhances the soil properties indirectly. A field experiment was $\infty n-$ ducted to evaluate the influence of organic manures viz., Farm Yard Manure (FYM), Vermicompost, Biochar, Biochar composite on soil properties, growth and yield of bhendi, Abelmoschus esculentus in Somayyanur soil series of Madurai district, Tamil Nadu. The experiment was laid out in randomized block design (RBD) with eleven treatments and three replications during the summer season (March - June) 2021 with the inclusion of inorganic fertilizers based on soil test crop response (STCR) based recommendation. Application of biochar composite $\left(5 \mathrm{t} \mathrm{ha}^{-1}\right)$ along with STCR based NPK (75\% STCR) increased the total carbon content in soil by $0.538 \%$. This, in turn, increased the available nitrogen status to 295 and $244 \mathrm{Kg} \mathrm{ha}^{-1}$ at 40 and 70 DAS, respectively. Similarly, the available phosphorous $\left(22.4,19.3 \mathrm{Kg} \mathrm{ha}^{-1}\right)$ and potassium $\left(344.70,323.70 \mathrm{Kg} \mathrm{ha}^{-1}\right)$ status also showed a considerable increase with the same treatment. The yield attributes of bhendi viz., fruit length, girth, weight, dry matter production and yield recorded maximum values of $15.23 \mathrm{~cm}, 6.93 \mathrm{~cm}, 21.56 \mathrm{~g}, 11.9 \mathrm{t} \mathrm{ha}^{-1}$ and $25.20 \mathrm{t} \mathrm{ha}^{-1}$ with the combined application of biochar composite and NPK. The findings revealed that $25 \%$ STCR based NPK could be reduced with the application of $5 \mathrm{t} \mathrm{ha}^{-1}$ of biochar composite, which is economically an option besides promoting soil health.
\end{abstract}

Keywords: Bhendi, Biochar, Biochar composite, Total carbon, Yield

\section{INTRODUCTION}

In recent years, global warming has been a threatening issue to human life. Increasing global warming, in particular, brings a series of negative effects to agricultural development. Concerning adverse effect of climate change, it is crucial to maintain threshold levels of organic matter and physical, chemical and biological properties of soil (Jiang et al., 2020). Biochar addition into the soil is recently considered as a feasible technique to increase the carbon status and soil quality. Biochar is a product of thermal decomposition of bio- mass by a process termed as pyrolysis at oxygenlimited conditions. Biochar is carbon-rich material that significantly increases the soil's organic matter content, leading to improved soil quality (Dos santos Farias et al., 2020). The use of biochar and organic and inorganic fertilizers has been reported to significantly improve microporosity, water holding capacity, and enzyme activities (Kannan et al., 2021). It also increase plant available nutrients in soil (Silber et al., 2010). Improvements in soil fertility and crop productivity depend mainly on the quantity of biochar used and soil types (Chen et al., 2019). The improvement in crop yield is 
attributed to increased nutrient availability, cation exchange capacity and water holding capacity of soil by the addition of biochar (Subedi et al.,2017).

In India, prosopis was introduced in the late 1900's to meet the fuel requirement of the rural poor. It is a phreatotype plant widely distributed in India and has survived where other tree species fail to grow and become a nuisance to the environment. It inhibits the germination of other species seeds that present in its vicinity. It has a negative impact on native vegetation (Edrisi et al., 2020) and interfere with water supply, hydrological functioning and herbivores grazing potential (Patnaik et al., 2017). Complete eradication was inevitable but we can reduce the menace of prosopis by converting them into agriculturally important carbon rich biochar. Therefore, in this study prosopis based biochar was prepared and biochar composite was prepared to study the effect of biochar and inorganic fertilizers on soil nutrient availability, carbon status and yield of bhendi (Abelmoschus esculentus (L)) crop.

\section{MATERIALS AND METHODS}

Prosopis biochar was prepared by heating wooden biomass wherein under oxygen-limited conditions at $450^{\circ} \mathrm{C}$ (e.g. slow pyrolysis), thermo-chemical conversion drives off the volatile components of the biomass and stabilizes the remaining carbon into a black, highly aromatic solid. The samples of this biochar were collected from the pyrolysis stove sieved using a $2 \mathrm{~mm}$ sieve. The biochar composite was prepared by mixing biochar and vermicompost at equal proportion and moisturized in alternate days for 30 days at vermicompost yard of Agricultural College \& Research Institute, Madurai. The manures were characterized as prescribed by Piper (1966), Pemberton (1945) and Jackson (1973) for total NPK. Total carbon content was analyzed by dry combustion method using elemental Total (TOC) analyzer (Allison et al.,1965). Biochar composite was applied at two different levels viz., 2.5 and $5 \mathrm{t} \mathrm{ha}^{-1}$ as soil application with $100 \%$ and $75 \%$ levels of Soil Test Crop Response (STCR) before sowing of bhendi seeds. The organic manures at recommended rates were applied evenly on their respective plots.

The field experiment was conducted during summer (March - June) 2021 at farmers field located in Kollankulam village of Madurai East block, Madurai district, Tamil Nadu. Bhendi hybrid Co-4 was used as a test crop. The experimental site is situated on $78^{\circ} 11^{\prime} \mathrm{E}$ latitude, $10^{\circ} 01^{\prime} \mathrm{N}$ longitude at $147 \mathrm{MSL}$. The soils of the experimental site belonged to Somayyanur soil series. The soil samples were collected and analyzed for $\mathrm{pH}$ (Potentiometry, Jackson, 1973), EC (Conductometry, Jackson, 1973), Texture (Piper,1966), Bulk density (Gupta and Dhakshinamurthi, 1980), Alkaline $\mathrm{KMnO}_{4}-\mathrm{N}$
(Subhaiain and Asija, 1956), Olsen-P (Olsen et al.,1954), $\mathrm{NH}_{4} \mathrm{OAc}-\mathrm{K}$ (Standford and English, 1949) and DTPA micronutrients (Lindsay and Norvell, 1978). The characteristics of the experimental soil, determined by standard methods, are presented in Table 2. The research experiment comprised of eleven treatments which were replicated thrice in randomized block design. The treatments comprise two levels of STCR based fertilizers viz., 75 and 100\% NPK with four types of organic manures viz., FYM, vermicompost, biochar and biochar composite. The treatments details are $T_{1}$ Control (Recommended dose of fertilizer 200:100:100 $\mathrm{kg}$ of NPK ha $\left.{ }^{-1}\right), \mathrm{T}_{2}, \mathrm{~T}_{4}, \mathrm{~T}_{6}, \mathrm{~T}_{8}, \mathrm{~T}_{10}$ consist $100 \%$ STCR based NPK with FYM $25 \mathrm{t} \mathrm{ha}^{-1}$, Biochar $5 \mathrm{t} \mathrm{ha}^{-1}$, Vermicompost $5 \mathrm{t} \mathrm{ha}^{-1}$. Biochar composite $2.5 \mathrm{t} \mathrm{ha}^{-1}$ and Biochar composite $5 \mathrm{t} \mathrm{ha}^{-1}$ respectively. $\mathrm{T}_{3}, \mathrm{~T}_{5}, \mathrm{~T}_{7}, \mathrm{~T}_{9}$, and $\mathrm{T}_{11}$ consist $75 \%$ STCR based NPK with FYM 25 $\mathrm{t} \mathrm{ha}^{-1}$, Biochar $5 \mathrm{t} \mathrm{ha}^{-1}$, Vermicompost $5 \mathrm{t} \mathrm{ha}^{-1}$, Biochar composite $2.5 \mathrm{t} \mathrm{ha}^{-1}$ and Biochar composite $5 \mathrm{t} \mathrm{ha}^{-1}$ respectively.

The recommended NPK dose of fertilizer (200:100:100 $\mathrm{kg}$ of NPK ha-1) for bhendi was applied in the form of urea, DAP and MOP at the rate of 349.7:217.4:166.7 $\mathrm{Kg} \mathrm{ha}^{-1}$. A full dose of phosphorous, potassium and half dose of nitrogen was applied as the basal and the remaining half dose of nitrogen at $30 \mathrm{DAS}$. Soil properties were analyzed at the critical stages of flowering and fruiting (40 and 70 DAS). Plant height was measured on $30,60,90$ DAS and fruit length $(\mathrm{cm})$, girth $(\mathrm{cm})$, weight $(\mathrm{g})$, yield $\left(\mathrm{t} \mathrm{ha}^{-1}\right)$ and dry matter production ( $\mathrm{t} \mathrm{ha} \mathrm{a}^{-}$ $\left.{ }^{1}\right)$ were computed at harvest stage. The statistical analysis was carried out by AGRES software at $5 \%$ level of significance.

\section{RESULTS AND DISCUSSION}

\section{Properties of Prosopis biochar}

Prosopis is extensively grown in many parts of Tamil Nadu and it is available in large quantities, particularly in dry tracts and wastelands. The data obtained from the Prosopis biochar is presented in Table 1. $\mathrm{pH}$ and EC of Prosopis biochar and biochar composite was 9.4, $0.21 \mathrm{dS} \mathrm{m}^{-1}$ and $8.50,0.38 \mathrm{dS} \mathrm{m}^{-1}$ respectively. The total carbon content and cation exchange capacity of the biochar was $839.8 \mathrm{~g} \mathrm{~kg}^{-1}$ and $21.3 \mathrm{c} \mathrm{mol}(\mathrm{p}+)$ $\mathrm{kg}^{-1}$ and biochar composite have $651.93 \mathrm{~g} \mathrm{~kg}^{-1}$ and $19.7 \mathrm{c} \mathrm{mol}(\mathrm{p}+) \mathrm{kg}^{-1}$. With respect to total nutrient content, Prosopis biochar and biochar composite had a high amount of carbon and a low amount of total nitrogen $\left(3.5\right.$ and $\left.4.2 \mathrm{~g} \mathrm{~kg}^{-1}\right)$. Prosopis biochar and biochar composite had a low amount of total phosphorus (1.02 and $1.2 \mathrm{~g} \mathrm{~kg}^{-1}$ ) and total potassium ( 4.3 and $4.1 \mathrm{~g} \mathrm{~kg}^{-1}$ ) and also contained exchangeable cations like calcium (12.2 and $15.3 \mathrm{~g} \mathrm{~kg}^{-1}$ ) and magnesium (0.47 and 0.92 $\left.\mathrm{g} \mathrm{kg}^{-1}\right)$. 
Table 1. Characterization of biochar and biochar composite

\begin{tabular}{llll}
\hline SI. No. & Characters & Prosopis Biochar & Biochar composite \\
\hline 1. & Moisture $(\%)$ & 1.52 & 2.13 \\
2. & Ash $\left(\mathrm{w} \mathrm{w}^{-1}\right)$ & 1.40 & 1.76 \\
3. & $\mathrm{pH}(1: 10$ solid water suspension) & 9.40 & 8.50 \\
4. & EC $\left(\mathrm{dS} \mathrm{m} \mathrm{m}^{-1}\right)(1: 10$ soil water extract) & 0.21 & 0.38 \\
5. & Cation exchange capacity $\left(\mathrm{c} \mathrm{mol}\left(\mathrm{p}^{+}\right) \mathrm{kg}^{-1}\right)$ & 21.3 & 19.7 \\
6. & Total carbon $\left(\mathrm{g} \mathrm{kg}^{-1}\right)$ & 839.80 & 651.93 \\
7. & Total Nitrogen $\left(\mathrm{g} \mathrm{kg}^{-1}\right)$ & 3.5 & 4.2 \\
8. & Total Phosphorus $\left(\mathrm{g} \mathrm{kg}^{-1}\right)$ & 1.02 & 1.2 \\
9. & Total Potassium $\left(\mathrm{g} \mathrm{kg}^{-1}\right)$ & 4.3 & 4.1 \\
10. & Calcium $\left(\mathrm{g} \mathrm{kg}{ }^{-1}\right)$ & 12.2 & 15.3 \\
11. & Magnesium $\left(\mathrm{g} \mathrm{kg}^{-1}\right)$ & 0.47 & 0.92 \\
\hline
\end{tabular}

Table 2. Characteristics of experimental soil

\begin{tabular}{cll}
\hline SI. No & Soil parameter & Soil characteristics \\
\hline 1 & $\mathrm{pH}$ & 7.95 \\
2 & $\left.\mathrm{EC}(\mathrm{dS} \mathrm{m})^{-1}\right)$ & 0.44 \\
3 & Texture & Clay loam \\
4 & Bulk density $\left(\mathrm{Mg} \mathrm{m}^{-3}\right)$ & 1.25 \\
5 & Particle density $\left(\mathrm{Mg} \mathrm{m}^{-3}\right)$ & 2.22 \\
6 & Pore space $(\%)$ & 44.00 \\
7 & Organic carbon $\left(\mathrm{g} \mathrm{kg}^{-1}\right)$ & 2.40 \\
8 & Available nitrogen $\left(\mathrm{kg} \mathrm{ha}^{-1}\right)$ & 252.00 \\
9 & Available phosphorous $\left(\mathrm{kg} \mathrm{ha}^{-1}\right)$ & 55.00 \\
10 & Available potassium $\left(\mathrm{kg} \mathrm{ha}^{-1}\right)$ & 353.00 \\
11 & DTPA extractable $\mathrm{Zn}\left(\mathrm{mg} \mathrm{kg}^{-1}\right)$ & 0.98 \\
12 & DTPA extractable Fe $\left(\mathrm{mg} \mathrm{kg}^{-1}\right)$ & 5.88 \\
13 & DTPA extractable Cu $\left(\mathrm{mg} \mathrm{kg}^{-1}\right)$ & 1.8 \\
14 & DTPA extractable $\mathrm{Mn}\left(\mathrm{mg} \mathrm{kg}^{-1}\right)$ & 4.19 \\
15 & Soil series & Somayyanur \\
\hline
\end{tabular}

Effect of biochar composite along with STCR based fertilizers on soil properties

\section{Soil pH and EC}

Application of biochar composite at $5 \mathrm{t} \mathrm{ha}^{-1}$ along with $75 \%$ STCR based NPK $\left(T_{11}\right)$ significantly influenced the soil $\mathrm{pH}$. The slight increase in average soil $\mathrm{pH}(0.4)$ over the initial values was primarily due to calcium, magnesium salts of chloride and carbonate present in biochar. Similar studies by Whitman et al. (2016) in corn (Zea mays) using pyrogenic organic matter revealed an increase in soil $\mathrm{pH}$. The application of biochar composite at $2.5 \mathrm{t} \mathrm{ha}^{-1}$ along with $100 \%$ STCR
NPK $\left(T_{8}\right)$ was on par with the application of biochar composite at $5 \mathrm{t} \mathrm{ha}^{-1}$ along with $100 \%$ STCR NPK $\left(\mathrm{T}_{10}\right)$ in influencing the soil $\mathrm{pH}$. The increase in average soil $\mathrm{pH}$ due to these treatments was mainly attributed to biochar's alkaline nature that increased the soil $\mathrm{pH}$ by 0.4 to1.2 $\mathrm{pH}$ units. Similar findings were reported by Pandian et al. (2016) in groundnut while applying prosopis biochar at the rate of $5 \mathrm{t} \mathrm{ha}^{-1}$ in sandy loam soil and Kannan et al. (2021) reported in Vigna mungo with the application of biochar and phosphobacteria that increased soil $\mathrm{pH}$ than biochar alone.

Application of biochar composite at $5 \mathrm{t} \mathrm{ha}^{-1}$ along with STCR based NPK significantly influenced the soil EC. 


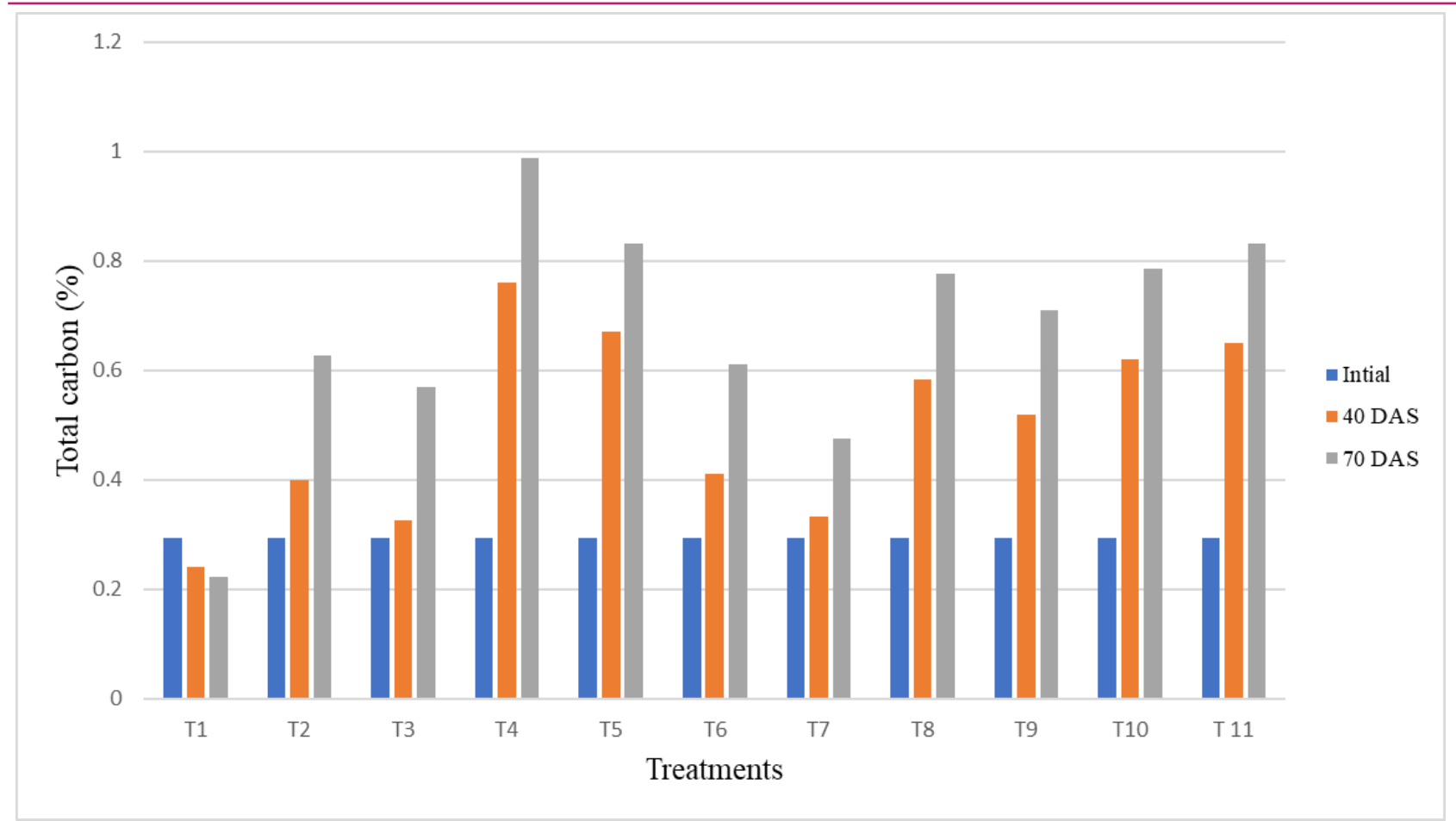

Fig. 1. Effect of biochar composite on total carbon content (\%) in soil

The slight increase in soil EC in biochar and biochar composite treatments over their initial values is mainly attributed to the addition of soluble salts through biochar, leading to an increase in electrolyte concentration. Nigussie et al. (2012) reported that applying maize stalk biochar at the rate of $10 \mathrm{t} \mathrm{ha}^{-1}$ increases the EC and $\mathrm{pH}$ in soils grown with lettuce crops.

\section{Available nitrogen}

Organic sources and inorganic fertilizer treatments significantly influenced soil available nitrogen content. The available nitrogen in the soil at flowering stage ranged from $252 \mathrm{~kg} \mathrm{ha}^{-1}$ in control to $295 \mathrm{~kg} \mathrm{ha}^{-1}$ in plots applied with biochar composite at $5 \mathrm{t} \mathrm{ha}^{-1}$ along with $75 \%$ STCR (Table 3). Similarly, the same treatment recorded soil available nitrogen content of $243.8 \mathrm{~kg} \mathrm{ha}^{-1}$ at the fruiting stage of bhendi. Thus, it was observed that soil application of biochar composite at $5 \mathrm{t} \mathrm{ha}^{-1}$ along with $75 \%$ STCR based NPK resulted in 17 and $16 \%$ increase in available nitrogen over the control plots (252 $\mathrm{kg} \mathrm{ha}^{-1}$ and $209 \mathrm{~kg} \mathrm{ha}^{-1}$ ) during flowering and fruiting stages respectively. This treatment was significantly on par with the application of biochar composite at $2.5 \mathrm{t}$ ha ${ }^{-1}$ with $100 \%$ STCR based NPK.

The increase in available soil nitrogen in biochar composite at $5 \mathrm{t} \mathrm{ha}^{-1}$ along with $75 \%$ STCR based NPK was mainly due to higher nutrient retention capacity and reduced nutrient leaching of the soils treated with biochar composite. Further, the efficient adsorption of ammonia $\left(\mathrm{NH}_{3}\right)$ at the planar surface of biochar might have reduced the volatilization loss, thus increasing the available $\mathrm{N}$ status in the soils applied with $5 \mathrm{t} \mathrm{ha}^{-1}$ of biochar composite along with STCR NPK. Tsutomu et al. (2004) reported bamboo charcoal carbonized at 500 ${ }^{0} \mathrm{C}$ having greater number of acidic functional groups, which lead to higher $\mathrm{NH}_{3}$ removal efficiency. Similar results were reported by Adekiya et al. (2020) in ginger with combined application of biochar and NPK fertilizers. Vaccari et al. (2015) also reported that wheat bran biochar increases soil available $\mathrm{NH}^{4+}$ in tomatoes. Singh et al. (2018) reported that application of biochar at increasing rates $\left(10,20\right.$ and $\left.40 \mathrm{t} \mathrm{ha}^{-1}\right)$ increased soil available $\mathrm{N}$ compared to the unamended control by $17.4 \%, 23.2 \%$ and $27 \%$ in wheat.

\section{Available phosphorous}

Application of organic sources viz., FYM, vermicompost, biochar and biochar composite significantly influenced the available $\mathrm{P}$ compared to unmanured control. Among the treatments, biochar composite at $5 \mathrm{t} \mathrm{ha}^{-1}$ with $75 \%$ STCR based NPK (113.2: 17.04: 97.12 NPK $\mathrm{Kg} \mathrm{ha}^{-1}$ ) recorded the highest soil available $\mathrm{P}$ of 22.4 and $19.3 \mathrm{~kg} \mathrm{ha}^{-1}$ at flowering and fruiting stages, respectively. This treatment was on par with biochar application at $5 \mathrm{t} \mathrm{ha}^{-1}$ with $100 \%$ STCR based NPK. The lowest values of 16.23 and $11.3 \mathrm{~kg} \mathrm{ha}^{-1}$ soil available phosphorous were observed at flowering and fruiting stages, respectively, in control plots that were applied with the recommended dose of fertilizer alone.

A significantly higher amount of soil available phosphorous in biochar composite applied plots might be due to its influence on cations $(\mathrm{Ca}, \mathrm{Mg}, \mathrm{Al}, \mathrm{Fe})$ that interacts 


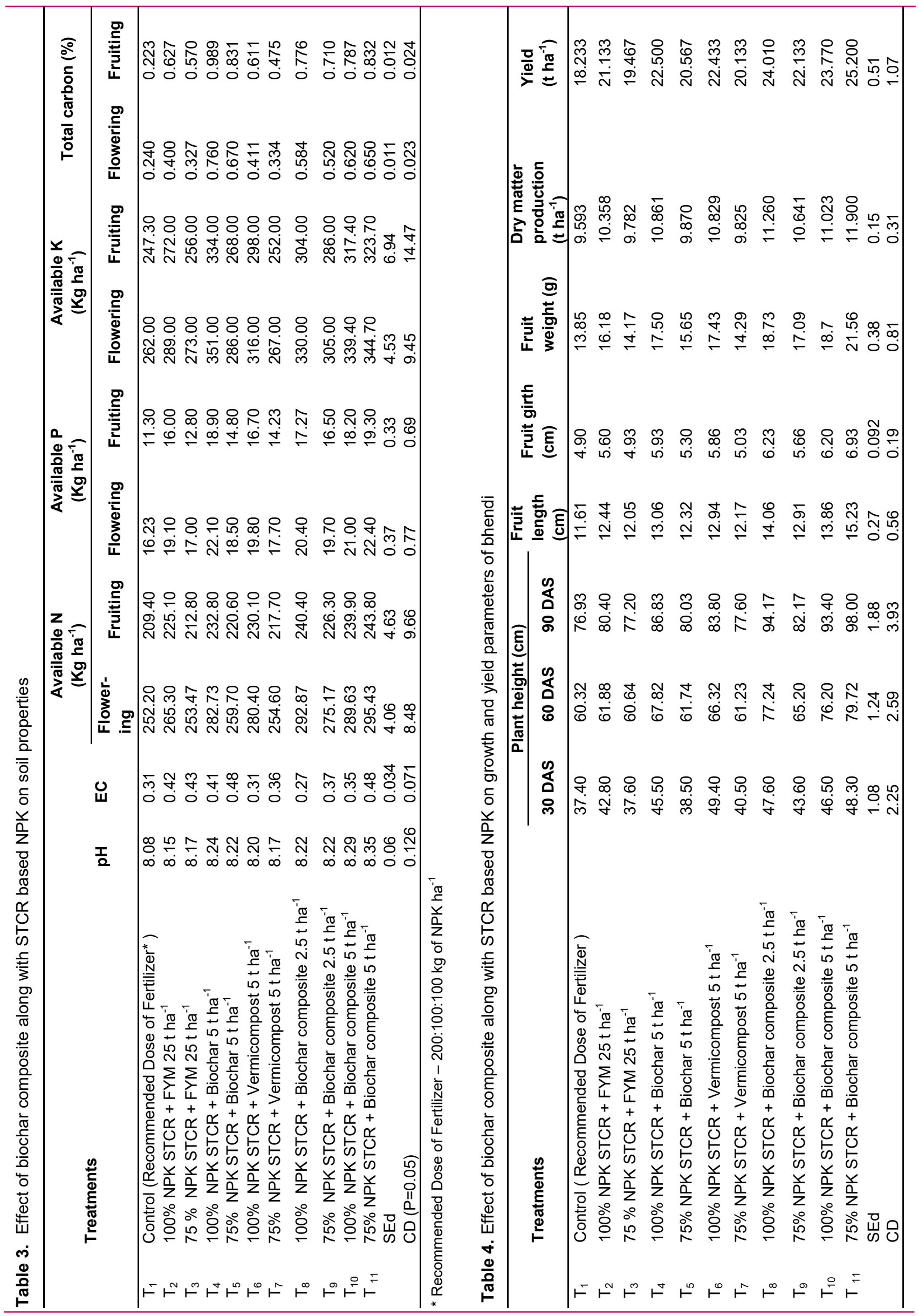


with phosphorous. Further, biochar's adsorption and desorption ability was found to influence the soil available $P$ as already suggested by Kannan et al. (2021) in Vigna mungo with the combined application of red gram stalk biochar and phosphobacteria. Pandian et al. (2016) reported increased soil available $P$ with the application of maize stalk biochar. Bornemann et al. (2007) reported that char produce from pyrolysis temperature of $850{ }^{\circ} \mathrm{C}$ had high surface area and sorption capacity. Application of biochar along with phosphorous protects $P$ from the precipitation in soil, thus enhancing its availability compared to control plots. The higher carbon content of biochar (83.9\%) might have increased the microbial activity facilitating the insoluble form of $\mathrm{P}$ into plant-available soluble form of $\mathrm{P}$. ElNaggar et al. (2019) also reported that the application of wood biochar with poultry manure composite increased the $P$ availability in soil.

\section{Available potassium}

The highest amount of $351 \mathrm{~kg} \mathrm{ha}^{-1}$ and $334 \mathrm{~kg} \mathrm{ha}^{-1}$ soil available potassium was observed in soils that received biochar at $5 \mathrm{t} \mathrm{ha}^{-1}$ along with $100 \%$ STCR based NPK at flowering and fruiting stages, respectively. This treatment was followed by that which received biochar composite at $5 \mathrm{t} \mathrm{ha}^{-1}$ with $75 \%$ STCR based NPK. The lowest amount of $262 \mathrm{~kg} \mathrm{ha}^{-1}$ and $247.3 \mathrm{~kg} \mathrm{ha}^{-1}$ of soil available potassium were observed in control plots. The increase in available $\mathrm{K}$ due to biochar application is contributed by the relatively higher content of potassium present in it as revealed by the basic characterization of the organic manures used in this study. Similar findings have also been observed by Pandian et al. (2016), who reported that applying red gram and cotton stalk biochar increases soil available potassium in groundnut.

\section{Total carbon}

The initial total carbon content of the soil was 0.294 percent. Application of biochar at the rate of $5 \mathrm{t} \mathrm{ha}^{-1}$ along with $100 \%$ STCR based NPK significantly increased the total carbon content to $0.760 \%$ and 0.989 $\%$ over the initial value at flowering and fruiting stages of bhendi crop respectively (Figure 1). The increase in total carbon content in soil mainly attributed by addition of carbon rich prosopis biochar into soil, which has total carbon content of $83.98 \%$. The lowest total carbon was observed in control plots. The influence of application of vermicompost $5 \mathrm{t} \mathrm{ha}^{-1}(12.6 \%)$ and application of FYM 25 t h.a ${ }^{-1}(16.6 \%)$ were on par with each other in influencing the total carbon status of soil. Shenbagavalli and Mahimairaja (2012) reported that prosopis biochar had high carbon content of $940 \mathrm{~g} \mathrm{~kg}^{-1}$. Similar findings were reported by Kannan et al. (2021) in Vigna mungo with the application of red gram stalk and Australian acacia biochar.

\section{Effect of biochar composite on growth and yield parameters of bhendi}

\section{Plant height}

A significant variation in plant height was recorded with application of different levels of biochar composite and STCR based NPK nutrients. The plant height was maximum $(98 \mathrm{~cm})$ in biochar composite at $5 \mathrm{t} \mathrm{ha}^{-1}$ along with $75 \%$ STCR based NPK while it was minimum $(76.93 \mathrm{~cm})$ in control (Table 4$)$. The positive effects of carbon content of the biochar based organic sources might have improved the soil environment thus enhancing the soil available nitrogen, contributing to its better vegetative growth than other treatments. Similar findings were observed by Dos santos Farias et al. (2020) reported that the application of sewage sludge biochar and sewage sludge biochar and raw sewage sludge increases the plant height of okra plants $60 \%$ and 55.4 $\%$, respectively, in comparison to control treatment. Gokila (2017) reported an increase in maize plant height with the combined application of prosopis biochar, azophos and $100 \%$ of the recommended dose of fertilizer. Hossain et al. (2019) reported that the application of fertilized farmyard manure biochar and fertilized domestic organic waste biochar increased the plant height of data shak (Amaranthus lividus) vegetables.

\section{Yield parameters, yield and dry matter production} Application of biochar composite at $5 \mathrm{t} \mathrm{ha}^{-1}$ along with $75 \%$ STCR based NPK recorded maximum fruit length (15.23), girth (6.93) and weight (21.56 g). This was followed by the application of biochar composite at $2.5 \mathrm{t}$ $\mathrm{ha}^{-1}$ along with $100 \%$ STCR based NPK which was also on par with application of biochar composite at $5 \mathrm{t}$ ha $^{-1}$ along with $100 \%$ STCR based NPK. Significant changes brought by addition of biochar composite and biochar on soil $\mathrm{pH}$, cation exchange capacity and soil organic matter might have helped nutrient retention in soil that increased the nutrient replenishment and nutrient availability, thus facilitating better nutrient uptake resulting in higher yields. Similar findings were reported by Kannan et al. (2013) and Oldfield et al. (2018), who have attributed the yield increase in field crops of rice (800\%), wheat $(250 \%)$ and groundnut (55\%) applied with biochar by improving the complex of physical, chemical and biological properties of the acidic soil as influenced by biochar application. Application of biochar composite at $5 \mathrm{t} \mathrm{ha}^{-1}$ along with $75 \%$ STCR based NPK recorded the highest yield of $25.2 \mathrm{t} \mathrm{ha}^{-1}$ and maximum dry matter production of $11.9 \mathrm{t} \mathrm{ha}^{-1}$. This was 38 $\%$ and $24 \%$ respective increase over control, respectively. The nutrients supplied by NPK fertilizer in this 
experiment might have been prevented from leaching in biochar and biochar composite treated plots, thus increasing the retention of these nutrients in the soil and by the crop contributing to higher yield. Similarly, Di et al. (2019) reported combined application of wheat straw biochar with vermicompost increased the rice yield compared to that vermicompost without biochar. Adekiya et al. (2020) reported increased rhizome yield of ginger with the application of hardwood biochar plus NPK fertilizer.

\section{Conclusion}

The results of the study on evaluation of biochar composite for improving soil properties and yield of bhendi (A. esculentus) proved that combined application of 75 $\%$ STCR with biochar composite at $5 \mathrm{t} \mathrm{ha}^{-1}$ positively influenced the physical properties (water retention and infiltration) and chemical properties (CEC, $\mathrm{pH}$, total carbon content) of soil thus contributing to better availability of nutrients. It also enhanced the nutrient uptake, yield $\left(25.2 \mathrm{t} \mathrm{ha}^{-1}\right)$ and biomass $\left(11.9 \mathrm{t} \mathrm{ha}^{-1}\right)$ of the bhendi crop. The findings also established the fact that $25 \%$ STCR based NPK can be reduced with the application of $5 \mathrm{t} \mathrm{ha}^{-1}$ of biochar composite, indicating the nutrient use efficiency and nutrient retention capacity potential of biochar and biochar composite.

\section{Conflict of interest}

The authors declare that they have no conflict of interest.

\section{REFERENCES}

1. Adekiya, A. O., Agbede, T. M., Ejue, W. S., Aboyeji, C. M., Dunsin, O., Aremu, C. O. \& Adesola, O. O. (2020). Biochar, poultry manure and NPK fertilizer: sole and combine application effects on soil properties and ginger (Zingiber officinale Roscoe) performance in a tropical Alfisol. Open Agriculture, 5(1), 30-39. http:// dx.doi.org/10.1515/opag-2020-0004

2. Allison, L. E., Bollen, W. B. \& Moodie, C. D. (1965). Total carbon. Methods of Soil Analysis: Part 2 Chemical and Microbiological Properties, 9, 1346-1366. https:// doi.org/10.2134/agronmonogr9.2.c38

3. Bornemann, L. C., Kookana, R. S. \& Welp, G. (2007). Differential sorption behaviour of aromatic hydrocarbons on charcoals prepared at different temperatures from grass and wood. Chemosphere, 67(5), 1033-1042.

4. Chen, W., Meng, J., Han, X., Lan, Y. \& Zhang, W. (2019). Past, present, and future of biochar. Biochar, 1 (1), 75-87. https://doi.org/10.1007/S42773-019-00008-3

5. Di, W. U., Yanfang, F. E. N. G., Lihong, X. U. E., Manqiang, L. I. U., Bei, Y. A. N. G., Feng, H. U. \& Linzhang, Y. A. N. G. (2019). Biochar combined with vermicompost increases crop production while reducing ammonia and nitrous oxide emissions from a paddy soil. Pedosphere, 29(1), 82-94. https://doi.org/10.1016/S1002-0160(18)
60050-5

6. Dos Santos Farias, D. B., de Freitas, M. I., Tadeu Lucas, A. A. \& Silva Gonzaga, M. I. (2020, March). Biochar and its impact on soil properties, growth and yield of okra plants. Colloquium Agrariae, 16 (2), 29-39. http:// dx.doi.org/10.5747/ca.2020.v16.n2.a356

7. Edrisi, S. A., El-Keblawy, A. \& Abhilash, P. C. (2020). Sustainability analysis of Prosopis juliflora (Sw.) DC based restoration of degraded land in North India. Land, 9(2), 59. https://doi.org/10.3390/land9020059

8. El-Naggar, A., Lee, S. S., Rinklebe, J., Farooq, M., Song, H., Sarmah, A. K. \& Ok, Y. S. (2019). Biochar application to low fertility soils: A review of current status, and future prospects. Geoderma, 337, 536-554. https:// doi.org/10.1016/j.geoderma.2018.09.034

9. Gokila, B. (2017). Climate Change Impact on Yield, Quality and Soil Fertility of Maize in Sandy Clay Loam as Influenced by Biochar and Inorganic Nutrients in Typic Haplustalf. International Journal of Current Microbiology and Applied Sciences, 6(11), 3150-3159. https:// doi.org/10.20546/ijcmas.2017.611.369

10. Gupta, R. P. \& Dakshinamoorthy, C. (1980). Procedures for physical analysis of soil and collection of agrometeorological data. Indian Agricultural Research Institute, New Delhi, 293.

11. Hossain, M. F. (2019). Effect of biochar and fertilizer application on the growth and nutrient accumulation of rice and vegetable in two contrast soils. Acta Scientific Agriculture, 3, 74-83.

12. Jackson, M. L. (1973). Soil chemical analysis prentice hall of India. Pvt. Ltd. New Delhi, 498.

13. Jiang, Z., Lian, F., Wang, Z. \& Xing, B. (2020). The role of biochars in sustainable crop production and soil resiliency. Journal of Experimental Botany, 71(2), 520-542. https://doi.org/10.1093/jxb/erz301

14. Kannan, P., Arunachalam, P., Prabukumar, G. \& Govindaraj, M. (2013). Biochar an alternate option for crop residues and solid waste disposal and climate change mitigation. African Journal of Agricultural Research, 8 (21), 2403-2412. https://doi.org/5897/AJAR12.2083

15. Kannan, P., Paramasivan, M., Marimuthu, S., Swaminathan, C. \& Bose, J. (2021). Applying both biochar and phosphobacteria enhances Vigna mungo L. growth and yield in acid soils by increasing soil $\mathrm{pH}$, moisture content, microbial growth and $\mathrm{P}$ availability. Agriculture, Ecosystems \& Environment, 308, 107258. http://dx.doi.org/1 0.1016/j.agee.2020.107258

16. Lindsay, W. L. \& Norvell, W. A. (1978). Development of a DTPA soil test for zinc, iron, manganese, and copper. Soil science society of America Journal, 42(3), 421428.

17. Nigussie, A., Kissi, E., Misganaw, M. \& Ambaw, G. (2012). Effect of biochar application on soil properties and nutrient uptake of lettuces (Lactuca sativa) grown in chromium polluted soils. American-Eurasian Journal of Agriculture and Environmental Science, 12(3), 369-376.

18. Oldfield, T. L., Sikirica, N., Mondini, C., López, G., Kuikman, P. J. \& Holden, N. M. (2018). Biochar, compost and biochar-compost blend as options to recover nutrients and sequester carbon. Journal of environmental management, 218, 465-476.

19. Olsen, S. R. (1954). Estimation of available phosphorus 
in soils by extraction with sodium bicarbonate (No. 939). US Department of Agriculture.

20. Pandian, K., Subramaniayan, P., Gnasekaran, P., \& Chitraputhirapillai, S. (2016). Effect of biochar amendment on soil physical, chemical and biological properties and groundnut yield in rainfed Alfisol of semi-arid tropics. Archives of Agronomy and Soil Science, 62(9), 12931310. https://doi.org/10.1080/03650340.2016.1139086

21. Patnaik, P., Abbasi, T. \& Abbasi, S. A. (2017). Prosopis (Prosopis juliflora): blessing and bane. Tropical Ecology, 58(3), 455-483.

22. Pemberton, H. (1945). Estimation of total phosphorus. Journal of American Chemical Society, 15, 383-395.

23. Piper, C. S. (1966). Soil and plant analysis, Hans. Publication. Bombay. Asian Edition, 368-374.

24. Shenbagavalli, S., \& Mahimairaja, S. (2012). Characterization and effect of biochar on nitrogen and carbon dynamics in soil. International Journal of Advanced Biological Research, 2(2), 249-255.

25. Silber, A., Levkovitch, I. \& Graber, E. R. (2010). pHdependent mineral release and surface properties of corn straw biochar: agronomic implications. Environmental Science and Technology, 44(24), 9318-9323.

26. Singh Mavi, M., Singh, G., Singh, B. P., Singh Sekhon, B., Choudhary, O. P., Sagi, S. \& Berry, R. (2018). Interactive effects of rice-residue biochar and $\mathrm{N}$-fertilizer on soil functions and crop biomass in contrasting soils. Journal of Soil Science and Plant Nutrition, 18(1), 41-59. http://
dx.doi.org/10.4067/S0718-9516201800500 0201

27. Stanford, G. \& English, L. (1949). Use of the flame photometer in rapid soil tests for $\mathrm{K}$ and $\mathrm{Ca}$. Agronomy Journal, 41(9), 446-447.

28. Subhaiaih, B. B. \& Asija, G. L. (1956). A rapid procedure for estimation of available nitrogen in soils. Current Science, 25, 259-260.

29. Subedi, R., Bertora, C., Zavattaro, L. \& Grignani, C. (2017). Crop response to soils amended with biochar: expected benefits and unintended risks. Italian Journal of Agronomy, 12, 161-173. http://dx.doi.org/10.4081/ija.201 7.794

30. Tsutomu, I., Takashi, A., Kuniaki, K. \& Kikuo, O. (2004). Comparison of removal efficiencies for ammonia and amine gases between woody charcoal and activated carbon. Journal of Health Science, 50(2), 148-153.

31. Vaccari, F. P., Maienza, A., Miglietta, F., Baronti, S., Di Lonardo, S., Giagnoni, L. \& Genesio, L. (2015). Biochar stimulates plant growth but not fruit yield of processing tomato in a fertile soil. Agriculture, Ecosystems \& Environment, 207, 163-170. https://doi.org/10.1016/j.agee.20 15.04 .015

32. Whitman, T., Pepe-Ranney, C., Enders, A., Koechli, C., Campbell, A., Buckley, D. H. \& Lehmann, J. (2016). Dynamics of microbial community composition and soil organic carbon mineralization in soil following addition of pyrogenic and fresh organic matter. International Society for Microbial Ecology, 10(12), 2918-2930. 